\title{
Talmud in the Mouth: Oral Recitation and Repetition through the Ages and in Today's Classroom
}

\section{Jonathan S. Milgram}

To the memory of a master pedagogue, our colleague and teacher

\section{Professor Dov Zlotnick z"l, 'the Tanna of Riverdale'}

Talmud scholars have recognized the fundamental role of oral recitation and repetition in the production, publication, and dissemination of rabbinic literature from the rabbinic to the geonic period. The part played by oral recitation and repetition in educational settings in centuries past, however, has been of lesser academic concern. Certainly, the simulation of ancient and medieval models of recitation and repetition in the context of the contemporary classroom has been, for the most part, ignored. ${ }^{1}$ The goal of this article is to chart and discuss the presumed functions of oral recitation and repetition in tannaitic, amoraic, and geonic educational contexts and entertain the possible benefits reaped from the integration of age-old study models into my contemporary college classroom. That is, to answer the question, "Can the imitation of these methods benefit modern pedagogy and contemporary students?" —and, if so, "How may these methods help my students learn how to read Talmud?"

1 The primary exception is the recent strategy of Pinchas Hayman employed for the study of Mishnah. See the summary of these methods, "Conference on Teaching Rabbinic Literature," http://www.brandeis.edu/mandel/teachingrabbinics/abstracts.html\# Anchor-The-7200. I thank Jon Levisohn for bringing this approach to my attention. 
In my undergraduate class, Sugyot about Sukkot, taught at the Albert A. List College of Jewish Studies, the secular Jewish Studies college of the Jewish Theological Seminary, ${ }^{2}$ I used a method of group oral recitation and repetition similar to what is known in contemporary education as "choral reading."3 First, I read the talmudic discussion, or sugya, out loud, section-by-section, and the entire class repeated each section in unison after me (for a detailed description, see below, "The Course and Its Goals"). The regular incorporation of this class exercise was meant, in part, to simulate the oration of texts assumed by scholars to have taken place during the tannaitic, amoraic, and geonic periods (first century CE-eleventh century CE).

Admittedly, there is an inherent anachronism in my imitation of ancient and medieval exercises in the context of the contemporary classroom under the guise of approximating what the talmudic sages and their textual inheritors, the geonim, practiced. Unquestionably, we cannot reproduce-in any real sense-whatever took place in the classrooms of the academies of yore, since we know so little about the activities of those educational settings, and our contemporary pedagogic framework is so dramatically different. ${ }^{4}$ Unfortunately, the historical truths will be concealed from us forever. We can, however, experiment with the imitation of these presumed practicesespecially when we observe the benefits of these methods to our students' education, as simulation can result in stimulation.

Below, I first explore some aspects of oral recitation and repetition in the educational contexts of the tannaim and amoraim and, the later geonim. Following, I introduce my college course and the goals I set out

23080 Broadway, New York, NY.

3 I wish to thank Ms. Lisa Schlaff, Director of Judaic Studies, SAR High School, Riverdale, NY, for first introducing this term to me when I once described to her how I intuited conducting my Talmud class. In searching for bibliography on choral reading, the following article by Joyce K. McCauley and Daniel S. McCauley, "Using Choral Reading to Promote Language Learning for ESL Students," The Reading Teacher 45 (March 1992): 526-33, served my needs exceptionally well and meaningfully informed the discussion herein.

4 One obvious distinction is that the tannaim, amoraim, and geonim recited and repeated oral texts. They had no written or printed exemplars in front of them. In my classroom, of course, we used printed editions. Regarding the situation among the rishonim, see the Addendum. 
for my students. Finally, I explain the actual process of recitation and repetition that took place during each class session and discuss why I think that the incorporation of these methods enhanced my students' educational experience, enabled the accomplishment of the academic goal to read and comprehend Talmud better, and even solidified the students' appreciation of talmudic literature. As evidence, I draw from the students' course evaluations.

\section{Oral Recitation and Repetition through the Ages}

In his seminal study, "The Publication of the Mishnah," Saul Lieberman argued that the Mishnah was never published in writing, ${ }^{6}$ only orally, ${ }^{7}$ and suggested how the Mishnah was published and disseminated viva voce in antiquity. In one notable instance, he entertained the role ${ }^{8}$ of orality in the educational context of the tannaim, saying that when the master taught his disciples:

[h] e taught the new Mishnah to the first Tanna; afterwards he taught it to the second Tanna ... then to the third etc.... After the ... Tannaim knew it thoroughly by heart, they repeated it in the college in the presence of the master who supervised its recitation, corrected it ... and gave it its final form. ${ }^{9}$

5 Saul Lieberman, "The Publication of the Mishnah," in Hellenism in Jewish Palestine (New York: Jewish Theological Seminary, 1950), 83-99.

6 This did not mean, argued Lieberman, that some writing of traditions did not exist; see Lieberman, "Publication," 87, where he discussed the private notes of students. However, in a more recent consideration of the data, Yaakov Sussmann argued that, in fact, tannaitic and amoraic rabbinic culture were qualitatively different from other contemporaneous societies that employed both oral and written media. According to Sussman, writing was not at all used by the rabbis in the creation or transmission of halakhic traditions. See Yaakov Sussmann, "Torah shebeal peh,' peshutah kemashmaah: koho shel kotzo shel yod," in Mehqerei Talmud III, Part I: Talmudic Studies Dedicated to the Memory of Professor Ephraim E. Urbach, ed. Yaakov Sussmann and David Rosenthal (Jerusalem: Magnes Press), 328.

7 For a challenge to this view, see Elizabeth Shanks Alexander, Transmitting Mishnah: The Shaping Influence of Oral Tradition (Cambridge: Cambridge University Press, 2006), 19-21.

8 He carefully begins his paragraph by stating, "[t]hen the procedure adopted by the master was probably something like the following ..." (Lieberman, "Publication," 93) [emphasis, JSM].

9 Ibid. 
Lieberman hypothesized that the educational function of oral recitation and repetition in antiquity was to internalize the text by committing it to memory ${ }^{10}$ and, later, to correct it, leading to the official and authoritative version. ${ }^{11}$

Yaakov Elman's recent claim for a "pervasive orality"12 in talmudic Babylonia (fourth century CE-fifth century CE) presented a compelling corollary to Lieberman's conception regarding the earlier tannaitic period. ${ }^{13}$ Elman asserted that the legal material found in the Babylonian Talmud was orally transmitted, and that the latest layer, made-up of dialectical and redactional elements, known as stam hatalmud, ${ }^{14}$ was also orally composed. ${ }^{15}$ As Elman correctly noted, a shift took place between the time of the production of the Babylonian Talmud's latest layers and the age of the geonim (roughly 589 CE-1038 CE), "[I]n the geonic period ... oral transmission of the Babylonian Talmud was a conscious choice, given the prevalence of book culture in Islamic Iraq." ${ }^{.16}$ Indeed, in this period, an age during which oral recitation and repetition of talmudic literature remained predominant and privileged, technologies for publishing (hand-written) books were prevalent. ${ }^{17}$ And, despite the existence of written book publishing, the new methods seemingly did not

10 Cf. Jacob Neusner, Oral Tradition in Judaism: The Case of the Mishnah (New York: Garland Publishing, 1987), 102. See also Dov Zlotnick, "Memory and the Integrity of the Oral Tradition," JANES 16-17 (1984-85): 229-41 [=Zlotnick, Iron Pillar Mishnah (Jerusalem: Bialik, 1988), 51-71; see also ibid., "Some Aspects of Mishnaic Repetition," 72-106].

11 Lieberman, "Publication," 87.

12 Yaakov Elman, "Orality and the Redaction of the Babylonian Talmud," Oral Tradition 14, no. 1 (1999): 52-99.

13 For suggestions on the possible differences between oral transmission in Palestine and Babylonia, see Martin Jaffee, Torah in the Mouth: Writing and Oral Tradition in Palestinian Judaism 200 BCE-400 CE (Oxford: Oxford University Press, 2001).

14 The bibliography on the nature and scope of this redactional layer is vast. For a summary of the issues, see both "Eliezer Diamond, "Rabbinics in the New Encyclopaedia Judaica," Judaica Librarianship 16, no. 17 (2011): 181-84 and Jonathan S. Milgram, "Then and Now: A Summary of Developments in the Field of Talmudic Literature through Contributions to the First and Second Editions of the Encyclopaedia Judaica," Currents in Biblical Research 11, no. 1 (October 2012): 131-33.

15 Elman, "Orality," 52.

16 Ibid., 57.

17 Ibid. See also the discussion in the magnificent study by Neil Danzig, "Mitalmud al peh letalmud bikhtav: al derekh mesirat hatalmud habavli velimudo biyemei habeinaim," Bar Ilan 30-31 (2006) [=Meir Simcha Feldblum Memorial Volume], 49-112. 
impact the oral study of Talmud among the geonim. This we are to understand from the tenth-century eye-witness account of Rabbi Nathan the Babylonian, who chronicled his visit to the geonic academies, ${ }^{18}$ describing the educational setting in which the orally transmitted text of the Babylonian Talmud was studied. He wrote: ${ }^{19}$

And when the head of the academy wants to examine them concerning their study texts (girsa), they gather around him in the four Sabbaths (i.e., weeks) of the month of Adar, and he sits and the first row recites before him, and the other rows sit silently ... Then he reads ${ }^{20}$ and they are silent.

The description here is of a repetition exercise, during which the students recited to the master the text they learned, and the master subsequently recited his version of the text back to them. ${ }^{21}$

The central role of oral recitation and repetition in the tannaitic, amoraic, and geonic periods is clear. What remains to be examined are the possible benefits, if any, of the imitation and integration of said methods into the contemporary college classroom. The potential pedagogic gains provided by oral repetition and recitation will, in the end, define the new role of oral recitation in the next stage of its historical implementation. It is my hope that my undergraduate course, Sugyot about Sukkot, marks the humble beginnings of that next phase.

18 On Nathan the Babylonian and the history of his narrative, see: M. Ben-Sasson, "The Structure, Goals and Content of the Story of Nathan HaBavli," Culture and Society in Medieval Jewry: Studies Dedicated to the Memory of Haim Hill Ben-Sasson, ed. M. Ben-Sasson, et. al. (Jerusalem: Zalman Shazar, 1989) [Hebrew], 137-96; and the literature cited in Rober Brody, The Geonim of Babylonia and the Shaping of Medieval Jewish Culture (New Haven: Yale University Press, 1997), 26-30.

19 This translation is from Brody, Geonim, 46. For the Hebrew translation of the original Judeo-Arabic, see A. Neubauer, Mediaeval Jewish Chronicles and Chronological Notes (Oxford: Clarendon Press, 1895), vol. 2, 87-88.

20 Although "reading" is usually done from a written text, here the verb is used to indicate oral recitation from memory. On the use of the verb "to read" as a description of oral recitation of Talmud, see Danzig "Mitalmud al peh," 77. And on the possibility that here the author of the text is influenced by the use of the verb "to read" in Arabic, which can designate oral recitation, see the literature cited in Danzig, "Mitalmud al peh," 77, note 99.

21 On this, see Danzig, "Mitalmud al peh," 77-78. 


\section{The Course and Its Goals}

The class I taught, Sugyot about Sukkot, was an undergraduate course designed for intermediate level students; that is, students with some previous exposure to Talmud study in the original. The material covered consisted of select discussions (sugyot) from the Babylonian Talmud's tractate Sukkah, relating to the fall holiday of Sukkot (known in English as the Feast of Tabernacles). The topics covered in these sugyot included the physical dimensions of the sukkah (temporary dwelling constructed for use on the holiday) (B. Sukkah 2a-2b); how many meals one is obligated to eat in the sukkah during the week-long festival (B. Sukkah $27 \mathrm{a}-27 \mathrm{~b}$ ); the required attributes of the lulav and etrog (respectively, the palm frond and citron fruit, shaken daily for the duration of the seven-day holiday) (B. Sukkah 31a-31b); the conditional gifting of the lulav to another for ritual use in expectation of its eventual return (B. Sukkah 41a); and the legality of using a stolen lulav on the first day of the holiday (B. Sukkah 29b-30a and 31a).

During the semester, the class met twice weekly for one hour and fifteen minutes. Of the nine students in the class, eight were graduates of Jewish high schools and had varying degrees of previous exposure to rabbinic texts in the original. The one student who was not a graduate of a Jewish high school took a course at the Jewish Theological Seminary in Talmud text the semester before taking my course. Certainly, none of the students had previously been taught through any method of group oral recitation and repetition. At most, some had been called on individually to read aloud from texts during high school Talmud classes.

The primary course goal was that students would be able to decode the text of the Babylonian Talmud in the original (Hebrew and Aramaic) by the end of the semester. Decoding, as I saw it in the context of this course (and other courses I teach), entailed the students mastering several skills the authors of other chapters in this volume emphasize as well: ${ }^{22}$ (1) knowing the meaning of every individual word, in context, in the talmudic

22 See, for example, chapters 3 and 4 by Jane Kanarek and Marjorie Lehman, respectively, in this volume. 
discussion; (2) reading the words and phrases in the original language(s) fluently; (3) pronouncing the words accurately; (4) understanding the function of technical terminology; and (5) following the flow of the logical argument presented in the text.

\section{Recitation and Repetition in the Context of the Contemporary College Classroom}

During the course of the semester, at each class session, I recited the text of the sugya, line-by-line, and the entire class repeated it verbatim in unison. My recitation included enunciation and inflection, emphasis on the proper pronunciation of each word in the text, and a stress on the technical role of each term and statement in the sugya. Below is a table, in which I describe the recitation and repetition exercises that took place by citing a selection of the sugya at B. Sukkah 2a in three columns (from right to left, as in Hebrew, columns I-III), with boxes representing rows (A-G). Each box in the column that is farthest right, column I, includes a discrete unit of the original text in Hebrew and Aramaic; the middle column II provides the translation ${ }^{23}$ and, in brackets, brief explanatory remarks made by me to the students; the column that is farthest left, column III, indicates the function (question, answer, etc.) of the text in column I for that row (A, B, C, D, E, F, or G). Before presenting the text and describing the oral recitation and repetition exercise, a summary of the Talmud's discussion is in order.

The first mishnah in tractate Sukkah invalidates a sukkah whose height is more than twenty amot (sing., amah; a talmudic measurement equivalent to the length from the tip of the middle finger to the elbow, also translated as "cubit"). The subject under discussion in the talmudic sugya is: Why is a sukkah built higher than 20 amot not acceptable? Three amoraic opinions are cited by Rabbah, Rabbi Zeira, and Rava; and, interspersed, are two challenges by the amora Abaye. The text follows in Figure 1:

23 The translation is based on Isidore Epstein, ed. The Babylonian Talmud (London: Soncino Press, 1935-1948), with changes as I felt appropriate. 


\begin{tabular}{|c|c|c|c|}
\hline III & II & 1 & \\
\hline Question & $\begin{array}{l}\text { How do we know this? [i.e., that } \\
\text { the maximum height of the sukkah } \\
\text { should be } 20 \text { cubits?] }\end{array}$ & מנא הני מילי? & A \\
\hline First answer & $\begin{array}{l}\text { Rabbah said: for Scripture states, } \\
\text { "That your generations may know } \\
\text { that I made the children of Israel } \\
\text { dwell in booths" (Lev } 23: 43 \text { ). } \\
\text { Until [the height of] } 20 \text { cubits, a } \\
\text { person knows that s/he dwells in a } \\
\text { sukkah; higher than } 20 \text { cubits, s/he } \\
\text { does not know that s/he dwells in } \\
\text { a sukkah, since his/her eye will not } \\
\text { catch sight of it [i.e., the schach, the } \\
\text { covering on top of the booth]. }\end{array}$ & 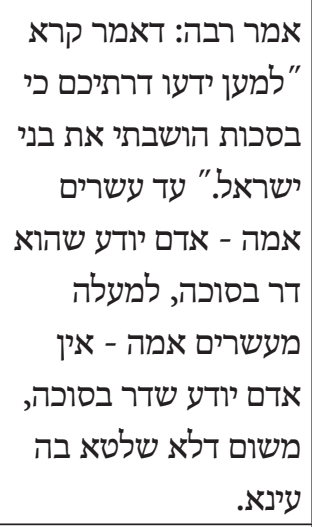 & B \\
\hline $\begin{array}{l}\text { Second } \\
\text { answer }\end{array}$ & $\begin{array}{l}\text { Rabbi Zeira said: From here [i.e., } \\
\text { from the following verse, it is de- } \\
\text { rived], "And there shall be a } \\
\text { sukkah for a shadow in the daytime } \\
\text { from the heat" (Isaiah } 4: 6 \text { ). [In } \\
\text { a sukkah] up to } 20 \text { cubits [high] } \\
\text { a person sits in the shade of the } \\
\text { sukkah, [but] higher than } 20 \\
\text { cubits, the person does not sit in } \\
\text { the shade of the sukkah, rather in } \\
\text { the shade of the walls. }\end{array}$ & 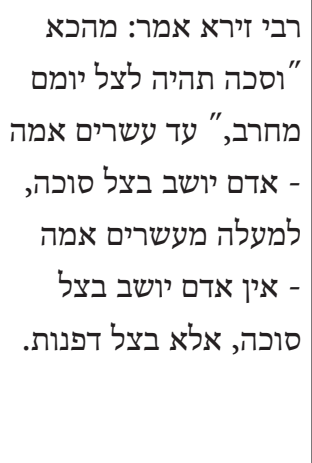 & C \\
\hline Challenge & $\begin{array}{l}\text { Abaye said to him: Rather, from } \\
\text { here, if a person makes his/her } \\
\text { sukkah in Ashtarot Karnayim [a valley } \\
\text { between two mountains where the } \\
\text { sun does not shine]. [Would it] also } \\
\text { not be a [valid] sukkah? }\end{array}$ & בעשת & $\mathrm{D}$ \\
\hline $\begin{array}{l}\text { Response } \\
\text { to challenge }\end{array}$ & $\begin{array}{l}\text { He [R. Zeira] said to him [Abaye], } \\
\text { there [i.e., in the second case], } \\
\text { remove the Ashtarot karnayim and } \\
\text { there will [still] be shade from the } \\
\text { sukkah. Here [i.e., the first case], } \\
\text { remove the walls of the sukkah and } \\
\text { there is not shade from the sukkah } \\
\text { [just shade from the walls]. }\end{array}$ & צמר ליה: התם, דל צרות קרנים - איכא & $E$ \\
\hline
\end{tabular}




\begin{tabular}{|c|c|c|c|}
\hline $\begin{array}{l}\text { Third } \\
\text { answer }\end{array}$ & $\begin{array}{l}\text { And Rava said: from here [i.e., } \\
\text { from this verse, it is derived], "You } \\
\text { shall dwell in sukkot seven days" } \\
\text { (Lev. 23:42). The Torah declared, } \\
\text { for the whole seven days leave your } \\
\text { permanent abode and dwell in a } \\
\text { temporary abode. [With a sukkah] } \\
\text { up to } 20 \text { cubits [high] one makes } \\
\text { his/her abode a temporary one; } \\
\text { [in one] higher than } 20 \text { cubits, one } \\
\text { does not make his/her abode tem- } \\
\text { porary, rather, a permanent abode. }\end{array}$ & 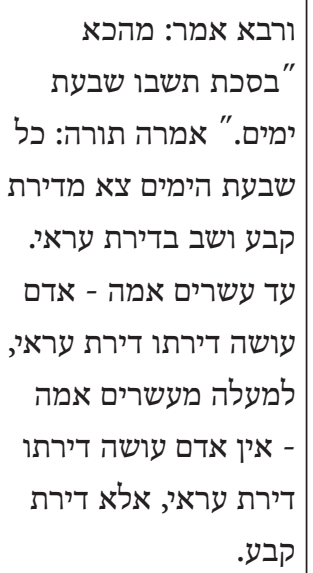 & $F$ \\
\hline Challenge & $\begin{array}{l}\text { Said Abaye to him [i.e., to Rava], } \\
\text { rather, from here, if he made walls } \\
\text { of iron and placed the [proper] } \\
\text { covering over them, would [it] also } \\
\text { not be a [valid] sukkah? }\end{array}$ & אמר ליה אביי: אלא & G \\
\hline
\end{tabular}

Figure 1 B. Sukkah 2a.

During the oral exercises, I first read a section of text in the original; for example, IA, out loud. Then I translated the text and gave minor explanatory notes, for instance, as per IIA, and indicated whether the text being recited and repeated was a question or an answer, such as, per IIIA. Following my recitation, translation, and explanation of an entire row, i.e., IA-IIIA, the students recited only the original text, IA, out loud in unison. Then the same procedure took place for IB, IIB, and IIIB; and then for IC, IIC, and IIC, and so on, until we completed the entire sugya in this fashion. After completing the sugya, we recited and repeated only column I (e.g., IA, IB, IC, and so on) - that is, without the translation and explanation in columns II and III-multiple times, until it was clear to me that the group was able to accurately express the contents of the sugya orally in unison. By hearing the group emphasize, enunciate, and inflect, I was able to gauge the group's mastery of the text (to read more on this, see below). For the most part, because of the repetition and recitation exercises, students would immediately realize whether the statement read was a question or an answer, whether 
a sage was simply stating something or aggressively defending a position and whether a proof was rebutted or upheld. After the oral exercise was completed, students asked content questions about the material and, together, we consulted the commentary by Rashi printed on the side of the page in standard printed editions. ${ }^{24}$

In the contemporary classroom, my students and I simulated-to a certain degree - the drills described by Lieberman for tannaitic educational methods and similar exercises likely carried out in talmudic Babylonia in the context of the "pervasive orality" of the day and noted in the eyewitness account of Nathan the Babylonian. When engaging the text through oral recitation and repetition, the students affirmed that they internalized elements of the material and "owned" the texts in a qualitatively different way than if they had just read the texts out loud as individuals, with me guiding their reading and its rhetorical qualities (see student evaluations below for their testimony). I suggest that group repetition helped students to be confident in their expressive reading of the dialectics of the sugya, without any individual being "put on the spot" to perform out loud the reading of the text in front of classmates. The group performance and repetition after my recitation provided a different and comfortable experience with a positive outcome: students learned to read Talmud better. Indeed, the other side of Walter Ong's observation that " $[\mathrm{w}]$ riting separates the knower from the known and thus sets up conditions for 'objectivity,' in the sense of personal disengagement or distancing ..." ${ }^{25}$ is that oral performance provides for the opposite: a cognitive closeness and unparalleled internalization of the text recited, as affirmed by student $\mathrm{G}$, "[o] ne of the things I love most about Talmud is the sound, or the niggun, which the learning brings, the moving sound that comes out of reading the text. Hearing or imagining the tone of

24 Rashi's commentary was also read out loud by me or read by a student when called on. However, students were not required to repeat the text of Rashi after me. In truth, I attempted at the beginning of the semester to have the students recite Rashi's commentary after me as well. However, Rashi's syntax - while concise and precise, is still, at times, longer and less predictable than the language of the Talmud-and proved to be too clumsy and difficult for the recitation and repetition exercises. Therefore, I abandoned the idea of students repeating this text.

25 Walter Ong, Orality and Literacy: the Technologizing of the Word (London and New York: Methuen, 1982), 45-46. 
voice that the rabbis used and repeating it out loud multiple times helps me to understand the argument of the text. Given my processing, this kind of learning helped me to better internalize the texts."

For some, the experience of oral recitation and repetition helped with, what we might term, fluency and grammatical accuracy when reading. It also provided a sense of appreciation of the Talmud's literary and intellectual program and, as a result, a connection with a broader ideal of Talmud study. As student A observed, "For me, my mistakes in punctuating the Talmud text prevent me from fully grasping the dynamics of the dialogue. Reading aloud in class helped me with punctuation and therefore also intonation. But even more than this practical matter, I think that reading the text aloud ... highlights the very nature of the Talmud and, by extension, Talmud study." Indeed, this student's comments relate well to the findings of some educators regarding the benefits of oral recitation and repetition of poetry and short stories in the classroom, including matters more mechanical, such as better diction ${ }^{26}$ and fluency. ${ }^{27}$ The student's evaluation also expresses an increased general appreciation for the literature studied, a benefit of oral repetition and recitation documented by some reading specialists. ${ }^{28}$ Student $\mathrm{C}$ emphasized a different enhancement to the ability to read Talmud, one that was provided by the oral exercises, "I think that I also had a better comprehension of what the sugya meant, because I could understand how individual words were emphasized within their sentences. So, when we spoke with certain emphasis on one word or the other, I could follow and comprehend the sentence itself better." Improved comprehension is another skill that reading teachers note students acquire through the practice of oral recitation and repetition. ${ }^{29}$

26 Donna R. Hall, "Oral Interpretation: An Approach to Teaching Secondary English," (paper presented at the joint meeting of the Central States Speech Association and the Southern Speech Communication Association, St. Louis, Missouri, 1987); cited in McCauley and McCauley, "Choral Reading," 527.

27 John M. Bradley and Mary R. Thalgott, "Reducing Reading Anxiety," Academic Therapy 22, no. 4 (1987) 349-58; cited in McCauley and McCauley, "Choral Reading," 527.

28 John W. Stewig, "Choral Speaking. Who has the Time?" Childhood Education 58, no. 1 (1981): 25-29; cited in McCauley and McCauley, "Choral Reading," 527.

29 See the bibliography noted for improved understanding and vocabulary; ibid., 527. 
The effects of the pedagogic paradigm of oral recitation and repetition on retention of material by students of English as a second language are discussed by Joyce K. and Daniel S. McCauley in their study, "Using Choral Reading to Promote Language Learning for ESL Students." ${ }^{30}$ I draw here, specifically, from the study by McCauley and McCauley on students of English as a second language, because the challenges confronted by this population are, at times, similar to those encountered by my students of Talmud, for whom Hebrew and Aramaic are certainly second languages. ${ }^{31}$ The study by McCauley and McCauley focused on the application of the pedagogic practice known as "choral reading," described by the authors in accordance with M. H. Arbuthnot's ${ }^{32}$ definition as, "the oral reading of poetry that makes use of various voice combinations and contrasts to create meaning or highlight the tonal qualities of the passage." ${ }^{33}$ It goes without saying that a dialectical literature such as the Talmud, composed and transmitted orally over generations, is expressed best when read out loud. But choral reading is more than just oral recitation. It is also about repetition, and it is this significant act that promotes the progress charted by reading teachers. As documented in McCauley and McCauley's article, reading specialists have discussed the benefits of oral recitation and repetition for over one-hundred years, starting with the now classic study by Edmund Burke Huey, The Psychology and Pedagogy of Reading. ${ }^{34}$ More recently, Peter A. Schreiber emphasized that repeated reading enhances the student's ability to "recognize what kind of syntactic phrasing is necessary to make sense of the passage." ${ }^{35}$ Other reading specialists stressed improved self-confidence and a sense of empowerment as a result of choral reading strategies. ${ }^{36}$ Student

30 See footnote 3.

31 In truth, even for the occasional native Hebrew speaker who may attend my class, talmudic language, with its integration of both Hebrew and Aramaic, is foreign. Only a select few will be comfortable with textual constructions because of backgrounds in intense Talmud study.

32 May Hill Arbuthnot, The Arbuthnot Anthology of Children's Literature (Glenview, IL: Scott Foresman and Co.), 1961.

33 McCauley and McCauley, "Choral Reading," 527.

34 (Boston: MIT Press), 1908.

35 Peter A. Schreiber, "On the Acquisition of Reading Fluency," Journal of Reading Behavior 12, no. 3 (1980): 182; cited in McCauley and McCauley, "Choral Reading," 528.

36 McCauley and McCauley, "Choral Reading," 527. 
$\mathrm{C}$ in my class echoed that this was also a byproduct of my course, "[o]verall, reciting the text orally was empowering, because it allowed me to understand the language used by the sugya."

More than just summarizing the research on choral reading, McCauley and McCauley argue for the benefits specific to students of English as a second language. In that setting, according to the authors, choral reading is successful, in part, because it is a "low anxiety activity":

All children can (and do) participate; there is no failure, no tension. The children are safe. Their individual mispronunciations are absorbed by the overriding voices of the group; even children with the least facility in English can experience fluent reading. ${ }^{37}$

For McCauley and McCauley, fluency is achieved in the group setting because of the creation of a "safe space." My students affirmed the safe and enjoyable context of oral recitation and repetition in my classroom, plainly stating, "This is a cool thing to experience" 38 and "it was actually pretty fun to read together." ${ }^{39}$

\section{Conclusions}

The implementation of oral recitation and repetition-age-old methods for the study of rabbinic texts-yielded positive results in my college Talmud classes. As evidenced by students' comments, the methods enabled the accomplishment of the course goals I set out for my students. Furthermore, the oral recitation and repetition was enjoyable and solidified the students' appreciation of talmudic literature.

The classroom recitation and repetition provided a template for the oral final exam, which was individual recitation of the texts in my office. ${ }^{40}$ During the exams, the students applied what they learned and were pushed to reproduce what had been done in class as part of the group, but this time as individuals (and without me reciting before them). Certainly, for some

37 ibid., 528.

38 Student A.

39 Student C.

40 There were two exams: a midterm and a final. 
students, the exam experience was not stress free. For some, the inability to rely on the group for support made the exercise extra challenging. Student C commented on this issue specifically, "I think that it would have been useful to do individual recitations [i.e., during class time], so that we could each practice the sugya with our own voice. Though, I still think that reading the text orally together did help me with the oral exam." All in all, the students performed exceptionally well. Student $G$ even attributed success during the exam to the group recitation and repetition experience, "Because our exams were oral, which I most prefer and find that I learn the most from, it was especially helpful to read out loud as a class and repeat multiple times the texts in front of us that we were later to be tested on."

The educational outcomes of oral recitation and repetition in my class, Sugyot about Sukkot, matched the results researched by advocates of choral reading in meaningful ways. The implementation of the strategies I describe here provided a positive educational experience for my students and significantly improved their Talmud text reading skills and comprehension. It is my hope that others, too, will benefit from the integration of oral recitation and repetition in their Talmud text classes when they teach their students how to read Talmud.

\section{Addendum}

\section{A Note on the Oral and the Written in the Period of the Rishonim and the Potential for Its Imitation in the College Classroom}

Talmudic texts were transmitted orally for centuries and only were officially committed to writing during the early Middle Ages. ${ }^{41}$ The Talmud being written down only affected educational settings by the time of the rishonim (1038-1565) and resulted in the eventual secondary role of oral recitation and repetition and a new primary position for written technology in Talmud study. Among the rishonim, in fact, the Talmud came to be studied exclusively in written form. ${ }^{42}$ The mode of instruction in the great medieval academies of Franco-Germany remained oral lectures however, as evidenced

41 See Danzig, "Mitalmud al peh."

42 Ibid., 49-50. 
in the time of the tosafists (11th century-13th century), when oral communication in the form of lectures still played a central role in educational settings, even while writing and the use of written Talmud texts had become the norm.

In a formal exercise of medieval instruction known as reportatio, the master dictated the text of his lesson to a disciple. Beryl Smalley described the program of the medieval reportatio from a student perspective:

The reportatio ... is a product of the classroom, arising directly from the needs of the student ... The 'reporter' is not a professional stenographer but a pupil, who, instead of merely taking notes, tries to get down a full, consecutive account of the lecture. ${ }^{43}$

As Haym Soloveitchik added, the process among the tosafists included the dictation of the lessons and interpretations by the teacher to the student, followed by the master's review of the student's report which, if necessary, he corrected and then certified as accurate. The text was then titled as tosafot (additions) or perush (commentary) of the master, as transcribed by the student. ${ }^{44}$ Hence, works such as Perush HaRashbam shenikhtav lifnei Rashi (The Commentary of Rashbam written before Rashi) were born. ${ }^{45}$ The authenticating mark of the reportatio was the addition at the end of the work of mipi rabi, certifying that the work was "from the mouth of my teacher," a formula preserved in better medieval manuscripts (but absent from others and printed editions). Some copyists, not understanding the significance of the formulation, removed the certifying "signature" from the end of the transcripts. Moreover, the names of the works themselves were shortened. The above title, for example, became just Perush HaRashbam (The Commentary of Rashbam), ${ }^{46}$ as it is known even today.

An imitation of the reportatio could be integrated into the contemporary college classroom and, I believe, could be positively productive. Students, after

43 The Study of the Bible in the Middle Ages (Oxford: Blackwell, 1952), 201.

44 Haym Soloveitchik, Wine in Ashkenaz in the Middle Ages (Jerusalem: Zalman Shazar 2008), 118.

45 Soloveitchik, Wine, 118.

46 Ibid. 
taking notes ${ }^{47}$ based on the class lecture and discussion, could submit their notes as a record of what was said to the instructor for "certification" that the contents are accurate. Indeed, the relationship of students' notes to the information and analysis provided by instructors is of significant concern to contemporary educational researchers, since the students' knowledge acquisition and methodological training depends not only on the professor's presentation, but also on the students' capable summarization for later consultation. As recently noted by Jaques van der Meer, professors should not assume that contemporary students come to the college classroom knowing how to take notes properly, and new methods for assisting student note-taking should be explored and implemented. Van der Meer emphasized that the inherent issues are not resolved by learning support structures implemented in institutions of higher education, since, often, note-taking is field specific. ${ }^{48}$ Developing appropriate note-taking for Talmud classes, therefore, is essential.

Partnering with our students on their note-taking — while arguably for some a seeming reinvention of how university instructors would approach teaching — can become an opportunity to better guide our students in developing skills necessary to master comprehension of rabbinic texts. Teachers requiring and then checking students' outlines and summaries of sugyot ${ }^{49}$ is, certainly, an advance in this regard. The challenge remains, however, to find a way to incorporate a running abbreviated commentary to the Talmud text in the outlines as well. ${ }^{50}$ Perhaps this problem could be resolved with the use of educational technology that would allow for an outline in electronic form, with links to windows that would then briefly explain the contents of a statement in the Talmud, a matter worthy of further consideration.

47 Whether electronically or in writing.

48 Jaques van der Meer, "Students' Note-taking Challenges in the Twenty-first Century: Considerations for Teachers and Academic Staff developers," Teaching in Higher Education 17, no. 1 (February 2012): 13-23 (and, for our discussion, especially 13-16).

49 See, for example, the discussion of outlines in Marjorie Lehman's "And No One Gave the Torah to the Priests: Reading the Mishnah's References to the Priests and the Temple" chapter 4 of this volume.

50 To be sure, some instructors require students to indicate in their outlines when the sugya records a tannaitic vs. an amoraic statement or where in the text a question vs. answer is provided. This does not constitute commentary in the classical sense of the word; as well, it does not, usually, include an explanation of the contents of the statements by the sages or questions and answers given. 